\title{
The Scythian Campaign of Philip II: A Problem of Reconstruction and Localisation
}

Alexander Anatolevich Kleymeonov ${ }^{\dagger}$

\section{Abstract}

The article considers the campaign of the Macedonian King Philip II against the Scythians in 339 B.C. The principal objectives of this study were to determine the plans of King Philip II and the balance of the forces of the opposing parties. The study also analysed the course of the military operations and the results of the campaign. The study uses a multifaceted approach to probe the ancient narrative sources. It also makes a content analysis of the data, retrieved from various national scientific schools. The analyses reveal that Philip conducted a military campaign against Ateas with the help of small expeditionary forces that moved from Byzantion to the mouth of the River Istros (Danube). Philip's enemy Ateas was a ruler of a small Scythian kingdom in Dobrudzha. The primary goals of the Macedonian king's campaign were to capture booty and help the local allies. A desire to morally compensate for the unsuccessful completion of the sieges of Perinthos and Byzantion was the central motive of the campaign. The result of the war was determined in a single pitched battle. Despite the defeat of the Scythians in Dobrudzha, Philip could not deliver the captured booty to Macedonia because of the limited forces. The Triballoi captured this booty, and this devalued the success of the whole Scythian campaign.

Keywords: Scythians, Philip II, Ateas, Dobrudzha, Warfare

\footnotetext{
+ Tula State Lev Tolstoy Pedagogical University, 125 Lenin Prospect, Tula, 300026, Russia, Email: aklejmeonov@mail.ru (C) 2018 Kleymeonov. This is an Open Access article distributed under the terms of the Creative Commons Attribution License (http://creativecommons.org/licenses/by/2.0), which permits unrestricted use, distribution, and reproduction in any medium, provided the original work is properly cited.
} 


\section{Introduction}

In ancient military history, many scientific problems have been considered in historiography, but they cannot be recognised as thoroughly studied. These include the Scythian campaign of the Macedonian King Philip II, which was repeatedly written by representatives of various national scientific schools. However, the existing reconstructions of the Macedonian King's campaign to the western Black Sea region have different significant shortcomings. They do not provide a comprehensive presentation of the place of the Scythian campaign in Philip's general strategy, nor of the tactical side of the war of the Macedonians with the Scythians, who were the bearers of military traditions unique to ancient Europe, created by the inhabitants of the steppe grassland of the northern Pontic area. This causes a new attempt to reconstruct the events of the war between Philip and the Scythians, which is presented in this article.

The structure of the article is determined by the state of historiography and the features of the source base. First, the primary methods of the research are defined, with particular attention to the studying of the ancient narrative sources. It then goes on to present the results by studying the sources and opinions of the modern researchers on the balance of the forces of the opposing sides, the history of the war and its scale. The "Discussion" section presents the author's reconstruction of the military events of the Scythian campaign of Philip II. In conclusion, the results of the war and its consequences are considered.

\section{Methods}

Macedonian King Philip II was the creator of the ancient Balkan superpower, which became the base for the accomplishments of his famous son Alexander the Great in Asia. The foreign policy of Philip II, who first came to power in a small and weakened state represented a consistent military expansion. Despite their great importance, we know little about some of the Macedonian conquests of that time. This is characteristic of the barbarian direction, to which the Greek writers paid little attention. Thus, we know little not only about the details of Philip II's campaign against the Scythian King Ateas but also about the general goals of the Macedonian King. In doing so, the study is an attempt to analyse as to why exactly the Scythian state became the target of the attack.

This study was based on the principle of a multifaceted approach to the ancient narrative sources. Ancient texts were considered in the context of scholarly interpretations. Due to the incomplete nature of historical data, a method of comparative historical analysis was used. When analysing the Scythian warfare, the historical sources were used in combination with the archaeological information. A content analysis was conducted when using historiography. A critical research issue is resolved through the historical reconstructive method. However, the evidence of the temporary presence of the Macedonian military forces in the Danubian region and the features of warfare of Dobrudzhan Scythians has not been considered in this study. The further archaeological research showed the validity of the reconstruction of the events presented in this article.

\section{Results}

The most linear and lengthy story of Philip's Scythian campaign was written by Justin, who retold the work of Pompeius Trogus, who, in turn, used the data of Theopompos (Grakov, 1971, p. 8; Hammond, 1991, p. 503). According to this source, the conflict erupted when the ambassadors of Ateas, who had difficulties in the war against the Histrianoi, arrived at Macedonia to speak to King Philip, who was engaged in the siege of Byzantion. Ateas asked Philip for help, promising to make him his heir. However, after the death of the Histrian king, Ateas renounced the treaty and sent back the Macedonian soldiers that had been sent to him earlier. As per their negotiations, the Macedonian king demanded monetary compensation from Ateas for the costs of the siege of Byzantion and the payment of the services of the soldiers, who were sent to help 
the Scythian ruler earlier. After all his demands were refused, Philip ceased the siege of Byzantion and marched against the Scythians, continuing to conduct negotiations through the ambassadors to conceal his intentions (IX, 2, 114). An earlier extract of the same work states that when Philip went to Scythia, he had hoped to capture booty to cover the incurred expenses $(I X, 1,9)$.

Ateas, with whom Philip began negotiations and then came into conflict, should probably be perceived as a ruler of the small Scythian Kingdom located in the lower Danube (predominantly in the territory of Dobrudzha) (Kallistov, 1968, p. 219; Polin, 1992, pp. 84-85; Andruh, 1995, pp. 76-80; Alekseev, 2003, p. 239; Buckler, 2003, p. 487; Yordanov, 2011, p. 202; Braund, 2015, pp. 354-355). He was however not the king of all Scythian lands from the Danube region to the Azov Sea, as written by some of the researchers (Shelov, 1971, pp. 55-56; Machinskij, 1971, p. 51; Gabriel, 2002, p. 1999). This can be agreed from the convincing arguments about the limited forces of Ateas, who had difficulties in the war against the Triballoi (Front. Strat., II, 4, 20, Polyaen., VII, 44, 1) and before the conflict with Philip, he asked the Macedonian king for military support in the struggle against the Histrianoi (Andruh, 1995, pp. 79-80). There is no consensus among specialists on the issue of comparing the Histrianoi with any of the communities of the region (Nicorescu, 1925, pp. 23-24; Danov, 1947, p. 52; Blavatskaya, 1952, pp. 86-87; Kallistov, 1968, pp. 216-217; Shelov, 1971, p. 60 ; Fol, 1975 , p. 51). However, there is no doubt that this community was a regional military-political player, whose potential was not comparable with the capabilities of all Scythian lands (Andruh, 1995, p. 80).

Now the question is what were the purposes of Philip II, who set out on a campaign against Ateas after a problematic campaign against Perinthos and Byzantion? Most researchers are unsatisfied with Justin's version explaining the actions of the Macedonian king for his desire to cover financial costs by means of Scythian booty. Some scholars believe that it was the desire to boost the morale of the army, which failed in East Thrace, and perhaps can be called as one of the motives of the Scythian campaign (Ellis, 1976, p. 185; Harris, 1995, p. 126). However, others indicate it as Philip's a desire to exert full control over the West Pontic coast (Blavatskaya, 1952, pp. 87-88). Besides, the intention of the Macedonian king to support the Getic king Kothelas, whose daughter was one of Philip's wives, is also one of the campaign prerequisites (Ellis, 1976, p. 185; Delev, 2008, p. 9). Additionally, there are several other reasons alongside a desire to capture rich booty, boost the morale of the troops and show the preserved power of Macedonian weapons to the inhabitants of the region, forced the Macedonian king to go north. We should cast doubt on the conclusions of some experts stating that the underlying causes of Philip's Scythian campaign included a desire to stop the rapid growth of Scythian influence in the Balkans, which supposedly endangered the entire system of power of the Macedonian king in Thrace (Nicorescu, 1925, p. 26; Shelov, 1971, p. 62). This conclusion is based on the exaggeration of the political influence and military resources of the kingdom of Ateas.

The number of troops used by Philip is of considerable interest for understanding the nature of the started military campaign. As is known from the work of Diodoros, the Macedonian king gathered a vast army of thirty thousand people to capture Perinthos and Byzantion (XVI, 74, 5). In this case, Justin mentions that during the decisive battle between Ateas and Philip, the numerical superiority was on the side of the Scythians (IX, $2,14)$. According to Gabriel, there is no reason to believe that the Macedonian king did not use all available forces for the campaign and, therefore, Philip met with the numerically superior army of the Scythians in the battle, which can be classified as the most large-scale in the ancient world (2010, p. 199). We fail to agree upon this conclusion. This is because the information about scarce military resources of Ateas and the recently ended difficult war with the Histrianoi cast doubt on the supposition 
that the Scythian king could gather such a large army. Besides, the nature of the description of events in the sources does not allow considering the Scythian campaign of Philip as comparable in scale and significance with his earlier campaign in East Thrace (Delev, 2008, p. 9). Contemporaries and ancient authors of later time paid little attention to this conflict. As rightly stated by Shelov, the Scythian campaign did not impress the Greeks, while Diodoros did not mention it at all $(1971$, p. 62$)$. The relatively short duration of the campaign indirectly points to the fact that the war between Philip and Ateas was a small-scale military conflict. Probably, Philip's Scythian campaign lasted from the beginning of spring till the beginning of summer in 339 B.C. (Ellis, 1976, p. 185; Delev, 2008, p. 9).

\section{Discussion}

These nuances make it possible to agree with the opinion presented in historiography, according to which the Macedonian king used only part of his forces in the war against Ateas. Philip, at the head of a small mobile corps not burdened with a wagon train, marched towards the Scythians along the seashore (Nicorescu, 1925, p. 26; Glotz, \& Cohen, 1936, p. 345). This assumption correlates well with the military campaign of Philip II in East Thrace, during which the Macedonian king launched an attack against Chersonesos at the head of a separate corps (Just., IX, 1, 7). The archaeological data also suggest the possibility of the presence of Macedonian troops in the area of the city of Histria, which has traces of destruction, the connection of which with the Scythian campaign of Philip II has not been precisely established, but it is possible (Yordanov, 2011, p. 202). Having ceased the siege of Byzantion and Perinthos, the Macedonian king ordered the central part of the Macedonian troops with a wagon train and siege vehicles to move west and to Macedonia. Philip himself headed the foremost soldiers of Macedonian infantry and cavalry and rapidly went north, intending to quickly defeat the Scythians and sooner return to Macedonia to take control of more critical Greek affairs. Based on Justin's information about the capture of 20,000 Scythian women and children by Macedonians (IX, 2, 15-16), Nicorescu used a well-known proportion of the ratio of men fit for war to the total population as 1:5. According to his conclusion, the army of Ateas consisted of about 4,000-5,000 soldiers, while Philip's corps consisted of 3,000 soldiers $(1925$, p. 27). It is impossible to consider these calculations as convincing since they are based on a controversial thesis about the conversion of all Ateas' Scythians into slavery. It seems that the actual number of the opposing troops was higher at least twice than the amount as indicated by Nicorescu.

However, little is known about the military operations between Philip and Ateas. The sources allow suggesting that the fate of the campaign was decided in a single battle (Kallistov, 1968, p. 219; Ellis, 1976, p. 186; Delev, 2008, p. 9). As for the spatial location of the battlefield, it is necessary to mention a fragment of the work attributed to Lucian, according to which the battle between Ateas and Philip took place near the river Istros $r$ (Macrob, 10). However, as Justin argues, while marching towards the Scythian lands, the Macedonian king tried to hide his intentions, informing Ateas through the ambassadors of his desire to place the statue of Herakles at the mouth of the river Istros (IX, 2, 10-11). The Macedonian conqueror was trying to conceal behind religious purposes a valid reason for the movement of his forces towards the mouth of the river Istros in the Danube. Accordingly, it can be concluded that Philip's invasion of the Scythian lands and the decisive battle with the Scythians took place not far from an area of confluence of the Danube into the sea. Little is also known about the pitched battle. Thus, it is reported that ninety-year-old Ateas fell in the battle (Macrob, 10). Justin writes that the Scythians were superior to the Macedonians in both courage and the number of soldiers, but were defeated by Philip's cunning moves (IX, 2 , 14). Frontinus left a somewhat unusual message about the battle of the Macedonians and the Scythians: it stated that Philip, fearing that the soldiers would not withstand the onslaught of the Scythians, placed the most 
reliable horsemen in the rear and ordered not to allow anyone to run away from the battle pitch and kill the most resistant of those who would run away. It is indicated that these measures have had an effect and the Scythians were defeated (II, 8, 14). Based on these incomplete data, as well as on the general information about the specifics of the Scythian warfare, experts repeatedly tried to reconstruct the course of the battle in general terms. Thus, it is widely believed that the combined use of phalanx and heavy cavalry became a guarantee of Philip's victory over the Scythian light cavalry (Blavatskij, 1950, p. 26; Shelov, 1971, p. 63). It is difficult to argue with this general comment considering the strengths of the Macedonian army as a reason for Philip's victory. However, to ensure that the actions of phalanx and cavalry were valid, the battle should have taken place in the format of close combat. Taking into account the leading role of horse archers in the troops of the Scythians, many of the researchers suppose that close combat was imposed on the Scythians by Philip (Gaebel, 2002, p. 153; Gabriel, 2010, p. 201; Ray, 2012, p. 130). However, the available data suggest that Ateas could prefer to meet the Macedonians in close combat. Such a scenario is well combined with the general context of the ancient information, which mentions both the courage of the Scythians (Just., IX, 2, 14) and their onslaught (Front. Strat., II, 8, 14). In scientific literature, starting with Blavatskij, it is noted that the Scythians knew how to use the compact construction of cavalry. Heavy cavalry headed by the king was at the head of the troops and followed by a worse equipped mass of soldiers, and close combat became crucial (Blavatskij, 1954, p. 24, Melyukova, 1964, p. 84; Chernenko, 1968, p. 168).

The archeological data also show an increasing importance of elite heavy equestrians in the Scythian warfare by the fourth century B.C.: an increase in the number of various armour (Melyukova, 1964, p. 85; Chernenko, 1968, p. $168)$, as well as the appearance of long lances effective in combat against enemy equestrians and infantrymen (Chernenko, 1984, p. 234). It can be assumed that Ateas, using his superiority in numbers over the enemy, carried out a massive attack on Philip's forces that were not successful. According to Nicorescu, Philip stopped the invasion of the cavalry of Ateas with the help of the phalanx that took a position between the hills, while the Macedonian cavalry took its place behind the infantry and did not allow them to flee (1925, p. 27). This reconstruction, based on a rather strange story of Frontinus, like Sekunda's version (2010, p. 451), is not convincing. Frontinus' story requires aobviously more critical attitude. One should agree with Hammond, who thought that Frontinus confused the actions of the Macedonian cavalry and infantry (Hammond, 1994, p. 136). The Scythians initially attacked the Macedonian cavalry. Close combat began, during which the Macedonian king strengthened the cavalry's battle order by involving infantrymen. This manoeuvre may be a trick that, according to Justin, allowed Philip to defeat the Scythians, who were superior in courage and number.

Speaking about the results of Philip's Scythian campaign, Machinskij drew attention to two fragments of Justin's work, in which it is mentioned that Philip of Macedon ran away from the Scythians (XXXVII, 3, 1, XXXVIII, 7, 3). Accordingly, Machinskij concluded that, despite the defeat and death of Ateas, the Scythians did not lose the war against Philip (1971, p. 51). This conclusion does not stand up to criticism since it ignores the data of Theopompos in favour of a rhetorical fragment. Philip's victory over the Scythians is confirmed not only by the death of Ateas in battle but also by the fact that the Macedonians captured rich booty. According to Justin, the Macedonian king did not find gold and silver from the Scythians, but he seized twenty thousand women and children into slavery, cattle, including twenty thousand of the best mares sent to Macedonia for horse breeding (IX, 2, 15-16).

Indeed, Philip's victory over Ateas' army was an outright military triumph. It can be assumed that Philip transferred the lands that were previously owned by Ateas to his ally Kothelas. The Macedonian king left the region with rich 
trophies. His military force moved west through the valley of the Iskar River to the area of modern Sofia to return to Macedonia, going down along the Strymon River (Ellis, 1976, p. 186). This return was not successful. Talking about the events after Ateas' defeat, Justin mentions that when Philip was returning from Scythia, the Triballoi stood in his way and demanded to give part of the booty for crossing their land. There was an armed clash, in which Philip suffered a wound to his thigh. Everyone thought that the Macedonian king died and, therefore, the booty was lost (IX, 3, 1-3). This incident is supposed to have taken place because the Triballoi placed an ambush on the way of the Macedonians going west across their land in the area of the Western Balkans or the Iskar Valley (Delev, 2008, p. 10). According to Buckler, the Triballoi were driven not so much by the desire to capture booty but by the desire to get rid of Philip, whose territorial expansion could further affect their land (2003, p. 488). There are practically no grounds for such a conclusion: the source points out the claims of the Triballoi for part of the Scythian booty. The limited number of Philip's corps, burdened by a mass of slaves and cattle, makes it possible to understand why the Triballoi decided to put forward an ultimatum and carried out the attack. This also explains how the Triballoi managed to obtain Scythian trophies, which could not be properly secured. Nevertheless, despite the king's injury and the loss of the booty, the Macedonian corps could return to Macedonia. Indeed, the primary credit for this goes to the Macedonian commanders who participated in the Scythian campaign with the king (Nicorescu, 1925, p. 28). They returned to Pella in July-August in 339 B.C. (Nicorescu, 1925, p. 27; Ellis, 1976, p. 185; Delev, 2008, p. 10).

\section{Conclusion}

Analysing the circumstances and results of the Scythian campaign of Philip II, it should be noted that the war against Ateas was successful. The Macedonian corps managed to defeat the army of the Scythian king and capture much booty. However, they failed to deliver all the trophies to Macedonia. In the fight with the Triballoi, Philip was wounded, and the booty was lost. Shelov notes that Philip's Scythian campaign is often regarded in literature as unsuccessful only because the Macedonian king lost the battle with the Triballoi. The researcher calls this assessment superficial: in his opinion, despite the unfortunate incident with the Triballoi, the primary goal of the campaign was achieved the Scythians suffered a decisive defeat, and their king was killed (Shelov, 1971, p. 63). We can partly agree with this conclusion: the military victory over the Scythians was won; however, they failed to use their trophies. The elimination of the Scythian domination in Dobrudzha has not led to the growth of Macedonian influence in Thrace. The actual result was strengthening and territorial expansion on the part of the Triballoi and the Getae, whose competitor was destroyed (Andruh, 1995, pp. 80-83; Delev, 2008, p. 11; Yordanov, 2011, p. 204). The unsuccessful armed conflict with the Triballoi did not allow Philip to replenish the treasury with the Scythian trophies that were one of the primary goals of the campaign. The moral effect of the victory over Ateas was also lost. The errors in the use of the military corps should be regarded as one of the main reasons. Its strength was enough to defeat the relatively small troops of Ateas, but not enough for accompanying a large number of slaves and cattle on the way to Macedonia. The end of the campaign was a continuation of the chain of failures of the Macedonian king and devalued the success of the entire Scythian campaign conducted by the best and most mobile part of the Macedonian army, which executed a determined attack on the kingdom of Ateas.

\section{References}

Alekseev, A.Yu. (2003). Khronografiya Evropeiskoi Skifii VII-IV Vv. do n.e. [The Chronography of European Scythia (7th-4th centuries B.C.)]. Saint Petersburg: Izdatelstvo Gosudarstvennogo Ehrmitazha.

Andruh, S.I. (1995). Nizhnedunaiskaya Skifiya v VI - nachale I v. do n.e. [The Lower 
Danubian Scythia in the 6th - early 1st centuries B.C.]. Zaporizhia, Ukraine: Zaporozhskii universitet.

Blavatskaya, T.V. (1952). Zapadnopontiiskie goroda v VII-I vekakh do n.e. [West Pontic Cities in the 7th-1st centuries B.C.]. Moscow: Izdatelstvo Akademii nauk SSSR.

Blavatskii, V.D. (1950). O strategii i taktike skifov [On the Strategy and Tactics of the Scythians]. In Kratkie soobshcheniya Instituta istorii materialnoi kultury AN SSSR [Brief Notes of the Institute of Archeology of the Academy of Sciences of the USSR] (Issue 34, pp. 19-30). Moscow: Izdatelstvo Akademii nauk SSSR.

Blavatskii, V.D. (1954). Ocherki voennogo dela v antichnykh gosudarstvakh Severnogo Prichernomoria [Essays of Warfare in the Ancient States of the Northern Black Sea Coast]. Moscow: Izdatelstvo Akademii nauk SSSR.

Braund, D. (2015). Thracians and Scythians: Tensions, Interactions and Osmosis. In J. Valeva, E. Nankov \& D. Graninger (Eds.), A Companion to Ancient Thrace (pp. 352-365). Oxford: Blackwell Publishing Ltd.

Buckler, J. (2003) Aegean Greece in the Fourth Century BC. Leiden: Brill.

Chernenko, E.V. (1984). Dlinnye kopya skifov [Long Spears of the Scythians]. In A.I. Melyukova, M.G. Moshkova \& V.G. Petrenko (Eds.), Drevnosti Evrazii v skifo-sarmatskoe vremya [Antiquities of Eurasia in the Scythian-Sarmatian Time] (pp. 231-235). Moscow: Izdatelstvo Nauka.

Chernenko, E.V. (1968). Skifskii dospekh [The Scythian Armor]. Kiev: Naukova dumka.

Danov, Ch. (1947). Zapadniyat bryag na Cherno more $v$ drevnostta [The Western Coast of the Black Sea in Antiquity]. Sofia: Universitetska pechatnitsa.

Delev, P. (2008). Philip II i Aleksadr Veliki v Severna Trakiya [Philip II and Alexander the Great in Northern Thrace]. In Proceedings of the Ruse Regional Museum of History. Book
XII. The World of the Getae (pp. 5-19). Ruse: RuseRegional Museum of History.

Ellis, J.R. (1976). Philip II and Macedonian Imperialism. Princeton, NJ: Princeton University Press.

Fol, A. (1975). Trakia i Balkanite prez rannoelinisticheskata epokha [Thrace and the Balkans until the Early Hellenistic Era]. Sofia: Nauka i izkustvo.

Gabriel, R.A. (2010). Philip II of Macedonia: Greater than Alexander. Washington: Potomac Books.

Gaebel, R.E. (2002). Cavalry Operations in the Ancient Greek World. Norman: University of Oklahoma Press.

Glotz, G., \& Cohen, R. (1936). Histoire grecque (Vol. III). Paris: Universite Paris Dauphine.

Grakov, B.N. (1971). Skify [The Scythians]. Moscow: Izdatelstvo Moskovskogo universiteta.

Hammond, N.G.L. (1994). Philip of Macedon. London: Gerald Duckworth \& Co Ltd.

Hammond, N.G.L. (1991). The Sources of Justin on Macedonia to the Death of Philip. The Classical Quarterly, 41/2(496-508), 00098388.

Harris, E.M. (1995). Aeschines and Athenian Politics. Oxford: Oxford University Press.

Kallistov, D.P. (1968). Rabstvo v Severnom Prichernomore V-III vv. do n.e. [Slavery in the Northern Black Sea Coast in the 5th-3th Centuries B.C.]. In D.P. Kallistov (Ed.), Rabstvo na periferii antichnogo mira [Slavery on the Periphery of the Ancient World] (pp. 193-221). Leningrad: Izdatelstvo Nauka.

Machinskij, D.A. (1971). O vremeni pervogo aktivnogo vystupleniya sarmatov $v$ Podneprove po svidetelstvam antichnykh pismennykh istochnikov [About the Time of the First Active Manifestation of Sarmatians in the Dnieper Region According to Ancient Text Sources]. In Arkheologicheskii sbornik Gosudarstvennogo Ehrmitazha [Archaeological Collection of the State 
Hermitage] (Issue 13, pp. 30-54). Leningrad: Izdatelstvo Gosudarstvennogo Ehrmitazha.

Melyukova, A.I. (1964). Vooruzhenie skifov [The Weapons of the Scythians]. Moscow: Izdatelstvo Nauka.

Nicorescu, P. (1925). La campagne de Philippe en 339. In V. Pârvan (Ed.), Dacia II (pp. 22-28). Bucarest: Cultura Natională.

Polin, S.V. (1992). Ot Skifii k Sarmatii [From Scythia to Sarmatia]. Kiev: Tipografiya FNPU.

Ray, F.E. (2012). Greek and Macedonian Land Battles of the 4th Century BC. Jefferson, NC: McFarland.

Sekunda, N. (2010). The Macedonian Army. In J. Roisman, \& I. Worthington (Eds.), A Companion to Ancient Macedonia (pp. 446-471). Oxford: Blackwell Publishing Ltd.

Shelov, D.B. (1971). Skifo-makedonskii konflikt $\mathrm{v}$ istorii antichnogo mira [Conflict of Scythians and Macedonians in the History of the Ancient World]. In Problemy skifskoi arkheologii. Materialy i issledovaniya po arkheologii SSSR [Problems of Scythian Archeology. Materials and Research on Archeology of the USSR] (Issue 177, pp. 54-63). Moscow: Izdatelstvo Akademii nauk SSSR.

Yordanov, K. (2011). Dobrudzha prez I-oto khil. pr. Chr. Geti [Dobrudzha During the I Mill. BC. Getae]. In B. Spasov (Ed.), Istoriya na Dobrudzha [History of Dobrudzha] (Vol. 1, pp. 131-234). Veliko Tarnovo: Faber.

\section{Acknowledgements}

The Ministry of Education and Science of the Russian Federation sponsored the project in 2017. The Project Number is 33.6496.2017.8.9. The findings of the project has given shape to this article 